\title{
THERMODYNAMIC PROPERTIES OF SULFURIC-ACID SOLUTIONS AND THEIR RELATION TO THE ELECTRO- MOTIVE FORCE AND HEAT OF REACTION OF THE LEAD STORAGE BATTERY
}

\author{
By D. Norman Craig and George W. Vinal
}

\section{ABSTRACT}

The heat of reaction in a lead storage cell involves reactions at the positive and negative plates and changes in the heat content of sulfuric-acid solutions. The latter is a variable factor, depending on the concentration of the solution. Newly computed values of the partial molal heat contents have made possible more accurate values of the heat of reaction, based on thermochemical data for comparison with similar values computed from the best available electrochemical data. Good agreement was found. The partial molal heat capacity of sulfuricacid solutions has also been recalculated. Critically selected values of electromotive force and temperature coefficient are given. These include previously unpublished values obtained at this Bureau in 1933. The partial molal volumes of sulfuric-acid solutions are given for a few concentrations and these are used for computing changes in electromotive force with change in pressure.

\section{CONTENTS}

I. Introduction

II. Thermochemical data for sulfuric acid

1. Relative heat content of solutions _._.

2. Relative partial molal heat contents

3. Heat capacity of solutions

4. Partial molal heat capacities

III. Electrochemical data of storage batteries.

1. Electromotive-force data

2. Temperature coefficient of electromotive force

IV. Heat of the lead storage-battery reaction

1. Based on electrochemical data $\ldots \ldots \ldots 5$

2. Based on thermochemical data

3. Comparison of thermochemical and electrochemical data_... 487

V. Effect of pressure on electromotive force.

VI. Conclusion.

VII. References

\section{INTRODUCTION}

In a previous paper by the authors [1], ${ }^{1}$ it was shown that the double-sulfate theory of reactions in the lead storage battery expressed by the equation

$$
\mathrm{PbO}_{2}+2 \mathrm{H}_{2} \mathrm{SO}_{4}+\mathrm{Pb} \rightleftharpoons 2 \mathrm{PbSO}_{4}+2 \mathrm{H}_{2} \mathrm{O}
$$

is consistent with the observed amounts of acid consumed and water formed when the cell is discharged. The experiments described in

\footnotetext{
1 Figures in brackets indicate the literature references at the end of this paper.
} 
that paper involve no assumptions regarding the correctness or applicability of any theory of the chemical reaction. The facts, established by experimental work, are (1) that $2.02 \pm 0.03$ equivalents of acid are used, and (2) that $1.96 \pm 0.19$ equivalents of water are formed by the passage of 1 faraday of electricity through the cell in the discharge direction. Thus to a higher degree of accuracy than previously attained, the results confirm the double-sulfate theory of chemical reactions in the battery.

Having established the reaction, thermodynamic reasoning may be used in comparing the heat of the reaction based on thermochemical data with calculations based on electrochemical data. Dolezalek [2] and others have made such comparisons previously on the assumption that the double-sulfate theory is correct, but more reliable thermal and electrical data are now available.

The data given in this paper on the properties of sulfuric acid have much wider application, however, than to the specific problem which is discussed.

\section{THERMOCHEMICAL DATA FOR SULFURIC ACID}

\section{RELATIVE HEAT CONTENT OF SOLUTIONS}

The energy changes (heat of reaction) in a storage cell involve all the constituents, including plates, and changes in the heat content of the solutions. For the solids, definite values of the heat of formation are available, and these values do not vary with the concentration of the solution. The variable factor depends on the concentration of the solutions, and the calculation of the heat of reaction involves the partial molal quantities for the solutions. These are, according to the nomenclature of Lewis and Randall [3],

$$
\begin{aligned}
& \bar{H}_{1}=\text { partial molal heat content of the water, and } \\
& \bar{H}_{2}=\text { partial molal heat content of the acid. }
\end{aligned}
$$

The heat content of a particular solution is given by the equation

$$
H=n_{1} \bar{H}_{1}+n_{2} \bar{H}_{2},
$$

where $n_{1}$ and $n_{2}$ are the number of moles of water and acid, respectively. If we deal with 1 mole of solution, this equation may be expressed in terms of mole fractions, $N_{1}$ and $N_{2}$ of the constituents.

Since

$$
N_{1}=\frac{n_{1}}{n_{1}+n_{2}} \text { and } N_{2}=\frac{n_{2}}{n_{1}+n_{2}} \text { and } N_{1}+N_{2}=1 \text {, }
$$

eq 1 becomes, for 1 mole of solution,

$$
H=N_{1} \bar{H}_{1}+N_{2} \bar{H}_{2} \text {. }
$$

Practically, the experimental data from which the partial quantities are calculated are based on observations of the heat liberated as increasing quantities of water are added to a specified amount of $\mathrm{H}_{2} \mathrm{SO}_{4}$, for example, 1 mole of $\mathrm{H}_{2} \mathrm{SO}_{4}$. These data are given in a table published by Bichowsky and Rossini [4]. However, these data are for a temperature of $18^{\circ} \mathrm{C}$ and require correction factors 
to convert them to $25^{\circ} \mathrm{C}$, if the results of the thermochemical calculations are to be compared with observed electrochemical data on batteries at $25^{\circ} \mathrm{C}$. Dr. Rossini has kindly supplied the corrections to convert his published data to $25^{\circ} \mathrm{C}$. Furthermore, this is the temperature at which measurements in dilute solutions have been made recently by Lange, Monheim, and Robinson [5].

Following the nomenclature in a paper by Rossini [6], Heat Contents in Aqueous Solutions, the relative apparent molal heat content of the solute is designated as $\Phi_{h}-\Phi_{h}{ }^{\prime}$, where $\Phi_{h}{ }^{\prime}$ is the apparent molal heat content at an arbitrarily chosen concentration. Taking the concentration $\mathrm{H}_{2} \mathrm{SO}_{4} \cdot 400 \mathrm{H}_{2} \mathrm{O}$ as the starting point, values of $\Phi_{h}-\Phi_{h}{ }^{\prime}$ at $25^{\circ} \mathrm{C}$ were calculated and are given in column 4 of table 1 . Those based on Rossini's data cover the range $n_{1}=6,400$ to $n_{1}=0$.

TABLE 1.-Heat content of sulfuric-acid solutions

\begin{tabular}{|c|c|c|c|c|c|c|c|}
\hline \multicolumn{3}{|c|}{ Concentration of solutions } & \multicolumn{2}{|c|}{$\begin{array}{l}\text { Relative apparent mo- } \\
\text { lal lieat content of } \\
\mathrm{H}_{2} \mathrm{SO}_{4} \text { at } 25^{\circ} \mathrm{C}\end{array}$} & \multirow{2}{*}{$\frac{d\left(\Phi_{h}-\Phi_{h}^{\circ}\right)}{d\left(m^{1 / 2}\right)}$} & \multicolumn{2}{|c|}{$\begin{array}{l}\text { Relative partial molal heat } \\
\text { content of - }\end{array}$} \\
\hline $\begin{array}{c}n_{1}, \text { moles of } \\
\text { water per } \\
\text { mole of } \\
\mathrm{H}_{2} \mathrm{SO}_{4}\end{array}$ & $\underset{\mathrm{H}_{2} \mathrm{SO}_{4}}{\text { Molality of }}$ & $\mathrm{H}_{2} \mathrm{SO}_{4}$ & $\Phi_{h}-\Phi_{h}^{\prime}$ & $\Phi_{h}-\Phi_{h}^{\circ}$ & & $\mathrm{H}_{2} \mathrm{SO}_{4} ; \overline{\mathrm{H}}_{2}-\overline{\mathrm{H}}_{2}^{\circ}$ & $\mathrm{H}_{2} \mathrm{O} ; \overline{\mathrm{H}}_{1}-\overline{\mathrm{H}}_{1}^{\circ}$ \\
\hline 1 & 2 & 3 & 4 & 5 & 6 & 7 & 8 \\
\hline $\begin{array}{r}51, \infty \\
200 \\
25,600 \\
12,800 \\
6,400\end{array}$ & $\begin{array}{l}0^{m} \\
.00108 \\
.00217 \\
.00434 \\
.00867\end{array}$ & $\begin{array}{l}\% \\
0 \\
.011 \\
.021 \\
.043 \\
.085\end{array}$ & $\begin{array}{r}\text { kcal/mole } \\
-5.02 \\
-3.86 \\
-3.48 \\
-2.94 \\
-2.12\end{array}$ & $\begin{array}{r}\mathrm{kcal} / \mathrm{mole} \\
0.00 \\
1.16 \\
1.54 \\
2.08 \\
2.90\end{array}$ & $\begin{array}{l}33.0 \\
30.8 \\
29.8 \\
27.4 \\
17.74\end{array}$ & $\begin{array}{r}\text { kcal/mole } \\
0.000 \\
1.665 \\
2.234 \\
2.889 \\
3.725\end{array}$ & $\begin{array}{r}k c a l / m o l e \\
0.000 \\
.000 \\
.000 \\
.000 \\
-.000_{1}\end{array}$ \\
\hline $\begin{array}{r}3,200 \\
1,600 \\
800 \\
400 \\
200\end{array}$ & $\begin{array}{l}.01734 \\
.03469 \\
.06938 \\
.1388 \\
.2775\end{array}$ & $\begin{array}{r}.17 \\
.34 \\
.68 \\
1.34 \\
2.65\end{array}$ & $\begin{array}{r}-1.54 \\
-0.98 \\
-.47 \\
+.00 \\
+.39\end{array}$ & $\begin{array}{l}3.48 \\
4.04 \\
4.55 \\
5.02 \\
5.41\end{array}$ & $\begin{array}{r}12.74 \\
8.28 \\
5.54 \\
3.32 \\
1.64\end{array}$ & $\begin{array}{l}4.318 \\
4.811 \\
5.280 \\
5.638 \\
5.842\end{array}$ & $\begin{array}{l}-.0003 \\
-.0005 \\
-.0009 \\
-.0015 \\
-.0028\end{array}$ \\
\hline $\begin{array}{r}100 \\
80 \\
60 \\
50 \\
40\end{array}$ & $\begin{array}{r}.5551 \\
.6938 \\
.9251 \\
1.1101 \\
1.3876\end{array}$ & $\begin{array}{r}5.16 \\
6.37 \\
8.32 \\
9.82 \\
11.98\end{array}$ & $\begin{array}{l}.60 \\
.65 \\
.72 \\
.76 \\
.84\end{array}$ & $\begin{array}{l}5.62 \\
5.67 \\
5.74 \\
5.78 \\
5.86\end{array}$ & $\begin{array}{l}0.72 \\
.58 \\
.54 \\
.54 \\
.58\end{array}$ & $\begin{array}{l}5.888 \\
5.912 \\
6.000 \\
6.065 \\
6.201\end{array}$ & $\begin{array}{l}-.0027 \\
=.0030 \\
=.0043 \\
=.0057 \\
-.0085\end{array}$ \\
\hline $\begin{array}{l}30 \\
25 \\
20 \\
15 \\
12\end{array}$ & $\begin{array}{l}\text { 1. } 8502 \\
\text { 2. } 2202 \\
\text { 2. } 7753 \\
\text { 3. } 7004 \\
4.626\end{array}$ & $\begin{array}{l}15.36 \\
17.88 \\
21.40 \\
26.63 \\
31.20\end{array}$ & $\begin{array}{l}.95 \\
1.05 \\
1.21 \\
1.53 \\
1.89\end{array}$ & $\begin{array}{l}5.97 \\
6.07 \\
6.23 \\
6.55 \\
6.91\end{array}$ & $\begin{array}{r}.70 \\
.82 \\
1.04 \\
1.40 \\
1.79\end{array}$ & $\begin{array}{l}6.446 \\
6.681 \\
7.096 \\
7.896 \\
8.834\end{array}$ & $\begin{array}{l}-.015_{9} \\
-.024_{4} \\
-.043_{3} \\
-.0898 \\
-.1604\end{array}$ \\
\hline $\begin{array}{r}10 \\
8 \\
6 \\
5 \\
4\end{array}$ & $\begin{array}{r}5.551 \\
6.938 \\
9.251 \\
11.101 \\
13.876\end{array}$ & $\begin{array}{l}35.25 \\
40.49 \\
47.57 \\
52.13 \\
57.65\end{array}$ & $\begin{array}{l}2.28 \\
2.86 \\
3.78 \\
4.43 \\
5.39\end{array}$ & $\begin{array}{r}7.30 \\
7.88 \\
8.80 \\
9.45 \\
10.41\end{array}$ & $\begin{array}{l}1.98 \\
2.20 \\
2.25 \\
2.30 \\
2.24\end{array}$ & $\begin{array}{r}9.632 \\
10.777 \\
12.222 \\
13.282 \\
14.581\end{array}$ & $\begin{array}{r}-.233_{2} \\
-.362_{2} \\
-.570_{4} \\
-.766_{3} \\
-1.042_{9}\end{array}$ \\
\hline \begin{tabular}{l|}
3 \\
2 \\
1.5 \\
1.0 \\
0.5
\end{tabular} & $\begin{array}{r}18.502 \\
27.75 \\
37.00 \\
55.51 \\
111.01\end{array}$ & $\begin{array}{l}64.47 \\
73.13 \\
78.40 \\
84.48 \\
91.59\end{array}$ & $\begin{array}{r}6.64 \\
8.56 \\
9.85 \\
11.70 \\
14.71\end{array}$ & $\begin{array}{l}11.66 \\
13.58 \\
14.87 \\
16.72 \\
19.73\end{array}$ & $\begin{array}{l}2.06 \\
1.76 \\
1.49 \\
1.27 \\
0.64\end{array}$ & $\begin{array}{l}16.089 \\
18.216 \\
19.401 \\
21.451 \\
23.102\end{array}$ & $\begin{array}{l}-1.476_{8} \\
-2.317_{8} \\
-3.021_{1} \\
-4.730_{6} \\
-6.742_{7}\end{array}$ \\
\hline 0 & $\infty$ & $\begin{array}{r}93.19 \\
100.00\end{array}$ & 18.52 & $\begin{array}{l}20.35 \\
23.54\end{array}$ & .00 & 23.54 & \\
\hline
\end{tabular}

If $\Phi_{h}{ }^{\circ}$ represents the apparent molal heat content at infinite dilution, then

$$
\Phi_{h}-\Phi_{h}{ }^{\circ}=\left(\Phi_{h}-\Phi_{h}{ }^{\prime}\right)+\left(\Phi_{h}{ }^{\prime}-\Phi_{h}{ }^{\circ}\right) .
$$

The first term on the right-hand side of the equation being known, it is necessary to find the value of the second term in order to evaluate $\Phi_{h}-\Phi_{h}{ }^{\circ}$ throughout the entire range of concentrations. 
Plotting on separate sheets, to the same scale, Rossini's data for $\Phi_{h}-\Phi_{h^{\prime}}$ and the data of Lange, Monheim, and Robinson [5] for $\Phi_{h}-\Phi_{h}{ }^{\circ}$ against the square root of the molality, for which the reason will appear later, one curve may be accurately fitted to the other in the range of overlapping values of $\Phi_{h}$. Then the value, $\Phi_{h}{ }^{\prime}-\Phi_{h}{ }^{\circ}$, is found to be $5.02 \mathrm{kcal} / \mathrm{mole}$ of $\mathrm{H}_{2} \mathrm{SO}_{4}$. Adding this to each value of $\Phi_{h}-\Phi_{h}{ }^{\prime}$ in column 4 of table 1 , the values of $\Phi_{h}-\Phi_{h}{ }^{\circ}$ given in column 5 are obtained. These values are the apparent molal heat contents of the respective solutions relative to infinite dilution. For concentrations below $n_{1}=6400$, the values of $\Phi_{h}-\Phi_{h}{ }^{\circ}$ have been supplied from the data of Lange, Monheim, and Robinson.

When sulfuric acid is diluted with water, the amount of heat liberated in passing from any one state of dilution to any other state of greater dilution can be found at once by subtracting the value of $\Phi_{h}-\Phi_{h}{ }^{\circ}$ for the greater dilution from the value of the same function at less dilution. A table of the heats of dilution can be readily calculated by subtracting the successive values of $\Phi_{h}-\Phi_{h}{ }^{\circ}$ from the value for 100-percent acid, $23.54 \mathrm{kcal} / \mathrm{mole}$ of $\mathrm{H}_{2} \mathrm{SO}_{4}$. Concentrated acid available commercially, however, is normally 93.19 percent $\left(66^{\circ}\right.$ Baumé), and if this is used, the heat liberated by diluting it is found by subtracting the respective values of $\Phi_{h}-\Phi_{h}{ }^{\circ}$ from the value for 93.19 percent, which is shown by the table to be $20.35 \mathrm{kcal} / \mathrm{mole}$ of $\mathrm{H}_{2} \mathrm{SO}_{4}$.

\section{RELATIVE PARTIAL MOLAL HEAT CONTENTS}

If the heat of the storage-battery reaction is to be calculated from thermochemical data, it is necessary to know the heat changes that occur when $\mathrm{H}_{2} \mathrm{SO}_{4}$ is removed from and $\mathrm{H}_{2} \mathrm{O}$ is added to an infinite amount of solution of some specified concentration, the process necessarily being isothermal. This involves the calculation of the relative partial molal values for $\mathrm{H}_{2} \mathrm{SO}_{4}$ and $\mathrm{H}_{2} \mathrm{O}$ from the experimentally determined relative apparent molal values. The relation between these quantities is expressed by the equation

$$
\Phi_{h}-\Phi_{h}^{\circ}=\bar{H}_{2}-\bar{H}_{2}^{\circ}+\frac{n_{1}}{n_{2}}\left(\bar{H}_{1}-\bar{H}_{1}^{\circ}\right),
$$

in which $\Phi_{h}-\Phi_{h}{ }^{\circ}$ is the relative apparent molal heat content, $\bar{H}_{2}-\bar{H}_{2} \circ$ and $\bar{H}_{1}-\bar{H}_{1}{ }^{\circ}$ are the relative partial molal heat contents of $\mathrm{H}_{2} \mathrm{SO}_{4}$ and $\mathrm{H}_{2} \mathrm{O}$, respectively.

Formulas for evaluating $\bar{H}_{2}-\bar{H}_{2}^{\circ}$ and $\bar{H}_{1}-\bar{H}_{1}^{\circ}$ are given in eqs 38 and 39 of Rossini's paper [6]. The molality being $m$, these equations are

and

$$
\bar{H}_{2}-\bar{H}_{2}^{\circ}=\Phi_{h}-\Phi_{h}{ }^{\circ}+\frac{1}{2} m^{1 / 2} \frac{d}{d m^{1 / 2}}\left(\Phi_{h}-\Phi_{h}{ }^{\circ}\right),
$$

$$
\bar{H}_{1}-\bar{H}_{1}^{\circ}=-\frac{m^{3 / 2}}{2(55,508)} \frac{d}{d m^{1 / 2}}\left(\Phi_{h}-\Phi_{h}{ }^{\circ}\right) .
$$

The values of $\Phi_{h}-\Phi_{h}{ }^{\circ}$ being available, the tangents, $d\left(\Phi_{h}-\Phi_{h}{ }^{\circ}\right) / d\left(m^{1 / 2}\right)$, of the curve $\Phi_{h}-\Phi_{h}{ }^{\circ}$ plotted against the square root of the molality can be evaluated. Values of the tangents at the respective points are given in table 1 . 
A prism of optical glass was used to obtain the tangents. A narrow band of paper having a small hole on the center line was fastened across the base of the prism vertically below the apex and parallel to it. A plotted point, when viewed from above, appeared as a double image through the hole in the paper. The prism was then rotated until the two arms of the curve, as viewed from above, were brought into coincidence at the apex of the prism. Either triangular face of the prism was then parallel to the tangent of the curve at the chosen point. To avoid systematic errors, readings were made by two observers with the prism in direct and reversed positions. Four or more determinations of the tangents were made at each plotted point, and these were all in satisfactory agreement. If the curvature was not too great, a prism having a base 4.8 by $3.5 \mathrm{~cm}$ was entirely satisfactory, but for a sharper curvature a smaller prism 2 by $2 \mathrm{~cm}$ was preferred.

In determining the tangents by this method, we are aware of the errors which may arise if the prism used is not of a suitable size for the particular curve. A too sharp curvature would prevent the use of such a method. This was not the case in this work. If one or at most a few tangents are to be measured, the method described would not be necessary, but in this work hundreds of tangents were measured and the use of the prisms made a great saving in time and increased the accuracy of the measurements. Another advantageous feature of the prisms was the ease and certainty with which the tangents could be measured at the required points.

As a further test of consistency of the measurements, the tangents were all plotted on a large scale against the square root of molality, and they were found to lie on a smooth curve. No adjustments were needed.

All the data necessary for calculating the partial molal quantities being available, the values of $\bar{H}_{1}-\bar{H}_{1}{ }^{\circ}$ and $\bar{H}_{2}-\bar{H}_{2}{ }^{\circ}$ at $25^{\circ} \mathrm{C}$ were tabulated in table 1 . The heat capacity of the solutions will be treated similarly.

\section{HEAT CAPACITY OF SOLUTIONS}

Other equally important properties of sulfuric-acid solutions are the heat capacities and corresponding partial quantities which can now be calculated from measured values of specific heat. Having the data for both heat content and heat capacity, the thermodynamic properties of sulfuric-acid solutions can be calculated for a wide range of concentrations and temperatures.

The method of computing the partial molal heat capacities is essentially the same as for the heat contents [7]. The basis of the calculations is the experimental values of the specific heats reported by Biron [8]. In Biron's original paper, which was published in Russian, more determinations are given than those subsequently quoted in other publications. Socolik [9] quotes part of the earlier work of Biron at $20^{\circ}$ and that of Savarizky at $40^{\circ}$, and adds his own work at $60^{\circ}$ and $80^{\circ} \mathrm{C}$. There is some uncertainty about the temperature applying to the values which he quotes from Biron. Actually, Biron's work was done at about $20^{\circ} \mathrm{C}$, but the change in heat capacity with change in temperature is small, as shown by a comparison of Biron's values with those of Socolik and Savarizky. In the region of 30 to 40 percent solutions, the differences are very small.

218089-40-8 
The results published by Bode [10], and Pascal and Garnier [11] have also been considered. These are in substantial agreement with Biron, but their determinations are far less numerous. The unpublished results of Taylor [12] for dilute solutions were of material help in drawing the curve of Biron's data. In addition to these authors there are many others whose results may be found in the technical literature. Biron's data, given in column 4 of table 2, cover the whole range of concentrations with numerous repeated observations at particular concentrations, and supply a consistent and comprehensive series of values. Smoothed values are given in column 5 of the same table. Although Biron's experiments are reported for $20^{\circ} \mathrm{C}$, they apply satisfactorily to a temperature of $25^{\circ} \mathrm{C}$. Comparing Biron's results at $20^{\circ}$ with those of Savarizky at $40^{\circ}$, the greatest difference of $0.01 \mathrm{cal}$ per gram degree occurs in the region 50- to 100-percent concentration. At concentrations of less than 40 percent, which includes the range for working batteries, the difference for a $20^{\circ}$ interval does not exceed $0.005 \mathrm{cal}$ per gram degree. The difference in specific heats for $20^{\circ}$ and $25^{\circ} \mathrm{C}$ in this range is therefore about 0.001 cal per gram degree or less.

TABLE 2.-Heat capacity of sulfuric-acid solutions

\begin{tabular}{|c|c|c|c|c|c|c|c|c|c|}
\hline \multicolumn{3}{|c|}{ Concentration of solutions } & \multicolumn{2}{|c|}{$\begin{array}{l}\text { Specific heats, } \\
20^{\circ} \mathrm{C} \text {. }\end{array}$} & \multirow{2}{*}{$\begin{array}{c}\text { Apparent } \\
\text { molal } \\
\text { heat } \\
\text { capacity, } \\
\Phi_{e}\end{array}$} & \multicolumn{2}{|c|}{ Tangents } & \multicolumn{2}{|c|}{$\begin{array}{l}\text { Partial molal heat } \\
\text { capacity of- }\end{array}$} \\
\hline $\begin{array}{c}n_{1} \text {, moles } \\
\text { of water } \\
\text { per mole } \\
\text { of } \mathrm{H}_{2} \mathrm{SO}_{4}\end{array}$ & $\begin{array}{l}\text { Molality } \\
\text { of } \mathrm{H}_{2} \mathrm{SO}_{4}\end{array}$ & $\mathrm{H}_{2} \mathrm{SO}_{4}$ & $\begin{array}{c}\text { Biron's } \\
\text { average } \\
\text { values }\end{array}$ & $\begin{array}{c}\text { Smoothed } \\
\text { values }\end{array}$ & & $d \Phi_{c} / d m^{1 / 2}$ & $d \Phi_{c} / d N_{2}$ & $\begin{array}{c}\mathrm{H}_{2} \mathrm{SO}_{4} \\
\bar{C}_{p_{2}}\end{array}$ & $\frac{\mathrm{E}_{2} \mathrm{O}}{\bar{C}_{p_{1}}}$ \\
\hline 1 & 2 & 3 & 4 & 5 & 6 & 7 & 8 & 9 & 10 \\
\hline $\begin{array}{r}1,600 \\
800 \\
400 \\
200 \\
150\end{array}$ & $\begin{array}{c}m \\
0.0347 \\
.0694 \\
.1388 \\
.2775 \\
.3700\end{array}$ & $\begin{array}{l}\% \\
0.34 \\
.68 \\
1.34 \\
2.65 \\
3.50\end{array}$ & $\begin{array}{r}c a l / g{ }^{\circ} \mathrm{C} \\
0.9968 \\
.9937 \\
.9877 \\
.9764 \\
.9688\end{array}$ & $\begin{array}{r}\text { cal } / g^{\circ} \mathrm{C} \\
0.9968 \\
.9937 \\
.9877 \\
.9762 \\
.9688\end{array}$ & $\begin{array}{r}\text { cal.mmole } \\
{ }^{\circ} \mathrm{C} \\
6.00 \\
6.85 \\
8.10 \\
9.82 \\
10.80\end{array}$ & $\begin{array}{r}+11.40 \\
+11.50 \\
+11.40 \\
+11.47 \\
+11.38\end{array}$ & & $\begin{array}{r}c a l / m o l e \\
{ }^{\circ} \mathrm{C} \\
7.06 \\
8.37 \\
10.22 \\
12.84 \\
14.26\end{array}$ & $\begin{array}{c}\text { cal/mole } \\
{ }^{\circ} \mathrm{C} \\
18.01 \\
18.01 \\
18.01 \\
18.00 \\
17.99\end{array}$ \\
\hline $\begin{array}{r}100 \\
50 \\
30 \\
20 \\
19\end{array}$ & $\begin{array}{l}.5551 \\
1.110 \\
1.850 \\
2.775 \\
2.921\end{array}$ & $\begin{array}{r}5.16 \\
9.82 \\
15.36 \\
21.40 \\
22.27\end{array}$ & $\begin{array}{l}.9551 \\
.9171 \\
.8768 \\
.8339 \\
.8277\end{array}$ & $\begin{array}{l}.9549 \\
.9177 \\
.8767 \\
.8339 \\
.8275\end{array}$ & $\begin{array}{l}12.32 \\
15.85 \\
19.35 \\
21.94 \\
22.10\end{array}$ & $\begin{array}{r}+11.35 \\
+11.25 \\
+10.95 \\
+4.45 \\
+3.10\end{array}$ & & $\begin{array}{l}16.55 \\
21.78 \\
26.80 \\
25.64 \\
24.75\end{array}$ & $\begin{array}{l}17.97 \\
17.90 \\
17.77 \\
17.83 \\
17.88\end{array}$ \\
\hline $\begin{array}{l}18 \\
17 \\
16 \\
15 \\
14\end{array}$ & $\begin{array}{l}\text { 3. } 084 \\
\text { 3. } 265 \\
\text { 3. } 469 \\
\text { 3. } 700 \\
\text { 3. } 965\end{array}$ & $\begin{array}{l}23.22 \\
24.25 \\
25.39 \\
26.63\end{array}$ & $\begin{array}{l}.8203 \\
.8122 \\
.8041 \\
.7948 \\
.7837\end{array}$ & $\begin{array}{l}.8205 \\
.8127 \\
.8041 \\
.7945 \\
.7837\end{array}$ & $\begin{array}{l}22.27 \\
22.32 \\
22.39 \\
22.40 \\
22.31\end{array}$ & $\begin{array}{r}+2.05 \\
+1.45 \\
+0.55 \\
-.40 \\
-1.15\end{array}$ & & $\begin{array}{l}24.07 \\
23.63 \\
22.91 \\
22.01 \\
21.16\end{array}$ & $\begin{array}{l}17.92 \\
17.94 \\
17.98 \\
18.04 \\
18.10\end{array}$ \\
\hline $\begin{array}{l}13 \\
12.5 \\
12 \\
11 \\
10\end{array}$ & $\begin{array}{l}\text { 4. } 270 \\
\text { 4. } 441 \\
\text { 4. } 626 \\
\text { 5. } 046 \\
\text { 5. } 551\end{array}$ & $\begin{array}{l}29.52 \\
30.34 \\
31.20 \\
33.11\end{array}$ & $\begin{array}{l}.7718 \\
.7647 \\
.7584 \\
.7412 \\
.7231\end{array}$ & $\begin{array}{l}.7717 \\
.7647 \\
.7579 \\
.7422 \\
.7238\end{array}$ & $\begin{array}{l}22.22 \\
22.01 \\
22.00 \\
21.70 \\
21.22\end{array}$ & $\begin{array}{l}-2.05 \\
-2.43 \\
-2.85 \\
-3.90 \\
-4.70\end{array}$ & & $\begin{array}{l}20.10 \\
19.45 \\
18.94 \\
17.32 \\
15.68\end{array}$ & $\begin{array}{l}\text { 18. } 18 \\
18.22 \\
18.27 \\
18.41 \\
18.57\end{array}$ \\
\hline $\begin{array}{l}9 \\
8 \\
7 \\
6 \\
5\end{array}$ & $\begin{array}{r}6.167 \\
6.938 \\
7.930 \\
9.251 \\
11.101\end{array}$ & $\begin{array}{l}37.69 \\
40.49 \\
43.75 \\
47.57 \\
52.13\end{array}$ & $\begin{array}{l}.7020 \\
.6776 \\
.6476 \\
.6152 \\
.5805\end{array}$ & $\begin{array}{l}.7023 \\
.6770 \\
.6476 \\
.6153 \\
.5801\end{array}$ & $\begin{array}{l}20.62 \\
19.85 \\
19.06 \\
18.77 \\
19.06\end{array}$ & $\begin{array}{r}-5.02 \\
-5.12 \\
-3.15 \\
0.00 \\
+1.94\end{array}$ & & $\begin{array}{l}14.39 \\
12.92 \\
14.63 \\
18.77 \\
22.29\end{array}$ & $\begin{array}{l}18.71 \\
18.88 \\
18.65 \\
18.02 \\
17.37\end{array}$ \\
\hline $\begin{array}{l}4 \\
3 \\
2 \\
1.5439 \\
1.25\end{array}$ & $\begin{array}{l}13.876 \\
18.502 \\
27.753 \\
35.952 \\
44.406\end{array}$ & $\begin{array}{l}57.65 \\
64.47 \\
73.13 \\
77.91 \\
81.33\end{array}$ & $\begin{array}{l}.5420 \\
.5012 \\
.4628 \\
.4518\end{array}$ & $\begin{array}{l}.5420 \\
.5012 \\
.4628 \\
.4518 \\
.4481\end{array}$ & $\begin{array}{l}20.15 \\
22.20 \\
26.03 \\
29.06 \\
31.52\end{array}$ & $\begin{array}{l}+3.35 \\
+3.75\end{array}$ & $\begin{array}{r}+49.6 \\
+50.6 \\
+41.0\end{array}$ & $\begin{array}{l}26.39 \\
30.26 \\
37.05 \\
41.13 \\
41.64\end{array}$ & $\begin{array}{r}16.46 \\
15.33 \\
12.51 \\
10.20 \\
9.92\end{array}$ \\
\hline $\begin{array}{l}1.1555 \\
1.0 \\
0.9246 \\
.6483 \\
.4856\end{array}$ & $\begin{array}{l}48.038 \\
55.51 \\
60.03 \\
85.62 \\
114.30\end{array}$ & $\begin{array}{l}82.49 \\
84.48 \\
85.48 \\
89.36 \\
91.81\end{array}$ & $\begin{array}{l}.4467 \\
.4408 \\
.4346 \\
.4016 \\
.3787\end{array}$ & $\begin{array}{l}.4467 \\
.4408 \\
.4346 \\
.4016 \\
.3787\end{array}$ & $\begin{array}{l}32.29 \\
33.16 \\
33.20 \\
32.40 \\
31.70\end{array}$ & & $\begin{array}{r}+34.5 \\
+11.7 \\
0.0 \\
-13.38 \\
-7.17\end{array}$ & $\begin{array}{l}40.87 \\
36.08 \\
33.20 \\
29.21 \\
30.12\end{array}$ & $\begin{array}{l}10.59 \\
15.09 \\
18.02 \\
22.94 \\
21.27\end{array}$ \\
\hline $\begin{array}{l}.2976 \\
.1428 \\
.000\end{array}$ & $\begin{array}{c}186.51 \\
388.70 \\
\infty\end{array}$ & $\begin{array}{l}94.82 \\
97.44 \\
100\end{array}$ & $\begin{array}{l}.3554 \\
.3404 \\
.3352 \\
\end{array}$ & $\begin{array}{l}.3554 \\
.3404 \\
.3352\end{array}$ & $\begin{array}{l}31.40 \\
31.68 \\
32.88 \\
\end{array}$ & & $\begin{array}{r}+0.10 \\
+4.95 \\
+15.08\end{array}$ & $\begin{array}{l}31.42 \\
32.22 \\
32.88 \\
\end{array}$ & $\begin{array}{r}17.96 \\
14.23 \\
2.94 \\
\end{array}$ \\
\hline
\end{tabular}


Having obtained smoothed values for Biron's published data, the apparent molal heat capacity, $\Phi_{c}$, was calculated. Letting $c_{p}$ represent the heat capacity of $1 \mathrm{~g}$ of solution (Biron's smoothed data), and $c_{p}{ }^{\circ}$ the heat capacity of $1 \mathrm{~g}$ of water, which is unity by definition,

$$
\Phi_{c}=\frac{1000}{m}\left(c_{p}-c_{p}{ }^{\circ}\right)+98.076 c_{p} .
$$

Values of $\Phi_{c}$ are given in column 6 of table 2. These were plotted against the square root of molality and against the mole fractions for ranges of concentration indicated in table 2. The values of the tangents shown in columns 7 and 8 were obtained by methods previously described in this paper.

\section{PARTIAL MOLAL HEAT CAPACITIES}

Having the values of $\Phi_{c}$ and $d \Phi_{c} / d\left(m^{1 / 2}\right)$, the partial molal heat capacities for $\mathrm{H}_{2} \mathrm{SO}_{4}$ and for water can be calculated by the following equations, respectively:

$$
\bar{C}_{p_{2}}=\Phi_{c}+\frac{1}{2}\left(m^{1 / 2} \frac{d \Phi_{c}}{d\left(m^{1 / 2}\right)}\right)
$$

and

$$
\bar{C}_{p_{1}}={\overline{C_{p_{1}}}}^{\circ}-\frac{m^{3 / 2}}{111.016} \frac{d \Phi_{c}}{d\left(m^{1 / 2}\right)},
$$

where $\bar{C}_{p_{1}}{ }^{\circ}$ is equal to the heat capacity of 1 mole of water. In the range of concentrated solutions, the corresponding equations used for calculating values of $\bar{C}_{p_{2}}$ and $\bar{C}_{p_{1}}$ are

$$
\bar{C}_{p_{2}}=\Phi_{c}+N_{1} N_{2} \frac{d \Phi_{c}}{d N_{2}}
$$

and

$$
\bar{C}_{p_{1}}=\bar{C}_{p_{1}}{ }^{\circ}-N_{2}{ }^{2} \frac{d \Phi_{c}}{d N_{2}} .
$$

In these equations the mole fractions of water and $\mathrm{H}_{2} \mathrm{SO}_{4}$ are indicated by $\mathrm{N}_{1}$ and $\mathrm{N}_{2}$, respectively. Values for ${\overline{C_{p}}}_{2}$ and ${\overline{C_{p}}}_{p_{1}}$ are given respectively in columns 9 and 10 of table 2.

One of the principal objects of the present work is to compare the results of thermal and electrical measurements by the application of thermodynamic theory. However, further calculations of the thermal properties of the materials involved are deferred until the electrical data have been presented and brought to the same point of being ready to calculate the heat of reaction electrochemically. 


\section{ELECTROCHEMICAL DATA OF STORAGE BATTERIES}

\section{ELECTROMOTIVE-FORCE DATA}

Many determinations of the emf of the storage battery as a function of the acid concentration have been made. A summary of the values reported by nine observers appeared in the second but not in the third edition of a book by one of the present authors [13]. Considerable differences between the various determinations are apparent. These differences can be attributed in part to uncertainties in (1) the electrical units employed by the earlier observers, (2) the concentrations of solutions, particularly the conversion of degrees Baumé to specific gravities or densities, (3) the temperatures at which the observations were made, and (4) the condition of the plates, some having been removed from the cells and washed. It is perhaps surprising that the differences, as shown in the table, are not greater. Most of the earlier papers are lacking in details which now seem essential for evaluating the results.

After a critical examination of these earlier determinations, those of Dolezalek [2], Kendrick [14], Thibaut [15], and Vinal and Altrup [13] were selected for inclusion in table 3 . Some of these measurements were made at $25^{\circ} \mathrm{C}$, and for the others sufficient data were given for calculating the results to $25^{\circ} \mathrm{C}$. The mean values for these four sets of data are given in column 7 of table 3 .

TABLE 3.-Electromotive force of lead-acid storage cells

\begin{tabular}{|c|c|c|c|c|c|c|c|c|c|c|c|}
\hline \multirow{2}{*}{$\begin{array}{c}\text { Specific } \\
\text { grav- } \\
\text { ity, } \\
25^{\circ} \mathrm{C} \\
25^{\circ} \mathrm{C}\end{array}$} & \multirow[b]{2}{*}{$\mathrm{H}_{2} \mathrm{SO}_{4}$} & \multicolumn{6}{|c|}{ Determinations on storage batteries, emf at $25^{\circ} \mathrm{C}$} & \multicolumn{4}{|c|}{$\begin{array}{l}\text { emf at } 25^{\circ} \mathrm{C} \text {; calculated from } \\
\text { electrode measurements }\end{array}$} \\
\hline & & $\begin{array}{l}\text { Dole- } \\
\text { zalek } \\
1898, \text { cal- } \\
\text { culated } \\
\text { to } 25^{\circ} \mathrm{C}\end{array}$ & $\begin{array}{c}\text { Ken- } \\
\text { drick } \\
1900 \text { at } \\
25^{\circ} \mathrm{C}\end{array}$ & $\begin{array}{l}\text { Thibaut } \\
1913 \text {, cal- } \\
\text { culated } \\
\text { to } 25^{\circ} \mathrm{C}\end{array}$ & $\begin{array}{c}\text { Vinal } \\
\text { and } \\
\text { Altrup } \\
1922 \text {, at } \\
25^{\circ} \mathrm{C}\end{array}$ & $\begin{array}{l}\text { Mean } \\
\text { of early } \\
\text { values }\end{array}$ & $\begin{array}{c}\mathrm{NBS} \\
1933 \text {, at } \\
25^{\circ} \mathrm{C}\end{array}$ & $\begin{array}{c}\text { Vos- } \\
\text { burgh } \\
\text { and } \\
\text { Craig } \\
1929\end{array}$ & $\begin{array}{c}\text { NBS } \\
1933\end{array}$ & $\begin{array}{c}\text { Harned } \\
\text { and } \\
\text { Hamer } \\
1935\end{array}$ & Mean \\
\hline 1 & 2 & 3 & 4 & 5 & 6 & 7 & 8 & 9 & 10 & 11 & 12 \\
\hline $\begin{array}{l}1.020 \\
1.030 \\
1.040 \\
1.050 \\
1.100\end{array}$ & \begin{tabular}{r|}
\multicolumn{1}{c}{$\%$} \\
3.05 \\
4.55 \\
6.04 \\
7.44 \\
14.72
\end{tabular} & $\begin{array}{l}1.906 \\
1.963\end{array}$ & $\begin{array}{l}v \\
1.844 \\
1.871 \\
1.889 \\
1.902 \\
1.954\end{array}$ & $\begin{array}{l}v \\
1.833 \\
1.851 \\
1.867 \\
1.879 \\
1.941\end{array}$ & $\begin{array}{l}1.890 \\
1.903 \\
1.956\end{array}$ & $\begin{array}{c}v \\
1.839 \\
1.861 \\
1.882 \\
1.898 \\
1.953\end{array}$ & $\begin{array}{c}v \\
1.855 \\
1.876 \\
1.892 \\
1.905 \\
1.962\end{array}$ & $\begin{array}{c}v \\
1.856 \\
1.878 \\
1.893 \\
1.909 \\
1.962\end{array}$ & $\begin{array}{c}v \\
1.882 \\
1.896 \\
1.908 \\
1.961\end{array}$ & $\begin{array}{c}v \\
1.855 \\
1.878 \\
1.895 \\
1.908 \\
1.960\end{array}$ & $\begin{array}{l}v \\
1.855 \\
1.879 \\
1.895 \\
1.908 \\
1.961\end{array}$ \\
\hline $\begin{array}{l}1.150 \\
1.200 \\
1.250 \\
1.280 \\
1.300\end{array}$ & $\begin{array}{l}21.38 \\
27.68 \\
33.80 \\
37.40 \\
39.70\end{array}$ & $\begin{array}{l}2.012 \\
2.054 \\
2.038 \\
2.125 \\
2.143\end{array}$ & $\begin{array}{l}2.000 \\
2.044 \\
2.084 \\
2.110 \\
2.127\end{array}$ & $\begin{array}{l}1.944 \\
2.043 \\
2.094 \\
2.126 \\
2.148\end{array}$ & $\begin{array}{l}2.000 \\
2.045 \\
2.091 \\
2.119 \\
2.138\end{array}$ & $\begin{array}{l}1.989 \\
2.047 \\
2.092 \\
2.120 \\
2.139\end{array}$ & $\begin{array}{l}2.005 \\
2.050 \\
2.098 \\
2.128 \\
2.148\end{array}$ & $\begin{array}{l}2.006 \\
2.049\end{array}$ & $\begin{array}{l}2.007 \\
2.051 \\
2.094 \\
2.121 \\
2.140\end{array}$ & $\begin{array}{l}2.005 \\
2.049 \\
2.097 \\
2.127 \\
2.147\end{array}$ & $\begin{array}{l}2.006 \\
2.050 \\
2.095 \\
2.124 \\
2.143\end{array}$ \\
\hline
\end{tabular}

1 International volts.

In column 8 of table 3 are given the results of a series of measurements made by the present authors in 1933 on pasted plates. Each cell contained two pasted plates which were made in the laboratory, using grids containing no antimony. The plates were therefore substantially free from local action, and ample time could be allowed for equilibrium to be established. Each cell contained a relatively large amount of electrolyte, the concentration of which was determined by weight titrations. Subsequently the plates were assembled in one 
cell, which was used for studying the chemical reactions in the lead storage battery. The paper on this subject by the present authors [1] contains a further description of the preparation of these plates.

All of the emf measurements were made on a potentiometer, using a standard cell connected in opposition. The standard cell was compared at frequent intervals with the Bureau's primary standard for the volt. This arrangement had the advantage of bringing all the measurements within the range of the potentiometer without the necessity of using a volt box, and significant errors in the calibration of the potentiometer were avoided. Each entry in the table is the mean value of two series of measurements. The first series was completed several months before beginning the second series, but the results were concordant to within a few millivolts.

Comparing the NBS values of 1933 with the earlier values, it is seen that with few exceptions the NBS values are higher. Although the reasons for this are not certainly known, it is probable that the presence of antimony in the grids of plates used in the previous investigations resulted in some local action, the effect of which would be to decrease slightly the concentration of electrolyte in the pores of the plates. Such an effect, if present, must have been much less in the NBS experiments of 1933 . Commercial plates with antimony grids are typical of the lead storage battery, but those without antimony most nearly represent the conditions for the fundamental equation of the battery, as expressed by the double-sulfate theory. It is evident from this table that the emf of the lead storage battery may be uncertain by several millivolts.

An independent method of obtaining the emf and temperature coefficients is by electrode combinations. Calculations based on such measurements have been made, and the emf data are reported in columns 9,10 , and 11 of table 3 .

Vosburgh and Craig [16] reported values for cells containing mercurous sulfate and five different preparations of lead dioxide. Computed values of the emf of the storage battery based on their measurements are given in column 9 of table 3 . The method for doing this will become apparent from a more detailed discussion of the NBS (1933) measurements on electrodes which were next in chronological order. These were made by the present authors on cells of the mercurous sulfate-lead dioxide type. The solutions in the various cells covered a range of 6 to 40 percent of $\mathrm{H}_{2} \mathrm{SO}_{4}$. The emf measurements were made with a potentiometer while the cells were in a thermostatically controlled oil bath regulated to $25^{\circ} \mathrm{C} \pm 0.01^{\circ} \mathrm{C}$.

In constructing the cells, use was made of glass blanks of $\mathrm{H}$-form similar to those ordinarily employed in making Weston normal cells. Two samples of lead dioxide were used. One of these was prepared electrochemically and the other by oxidation of $\mathrm{Na}_{2} \mathrm{PbO}_{3}$ by bromine in an alkaline solution.

If the emf of these cells, reaction 1 in table 4 , is combined with the known emf of reactions 2 and 3 , the emf of the lead storage battery, reaction 4 can be computed by the method indicated in the table. The emf of reaction 2 was determined previously by Henderson and Stegeman [17] and that of reaction 3 by Gerke [18]. Their values are given in table 4 , together with their respective values of $d E / d T$, which will be discussed in the following section. 
Harned and Hamer [19] reported the emf of lead dioxide-hydrogen cells containing sulfuric-acid solutions up to 40-percent acid. By combining the emf of these cells with the emf of other cells mentioned by them, they calculated the emf of the lead-acid storage cell. From a plot of their data, we have read the values given in column 11 of table 3 .

TABLE 4.-Electromotive force and value of $\Delta E / \Delta T$ for cell reactions

[Values of $a$ and $b$ are dependent on molality of $\mathrm{H}_{2} \mathrm{SO}_{4}$ solutions]

\begin{tabular}{|c|c|c|}
\hline Reactions & $\begin{array}{l}\text { Electromo- } \\
\text { tive force at } \\
25^{\circ} \mathrm{C}\end{array}$ & $\Delta E / \Delta T$ \\
\hline 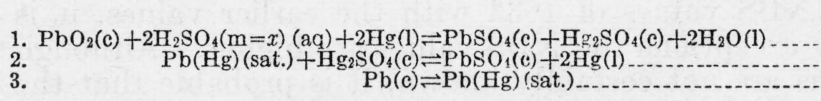 & $\begin{array}{l}v \mathrm{a} \\
\boldsymbol{a} \\
0.9646 \\
\quad .0057\end{array}$ & $\begin{array}{l}v /{ }^{\circ} C \\
b \\
0.00017 \\
\text { b. } 00002\end{array}$ \\
\hline 4. $\mathrm{PbO}_{2}(\mathrm{c})+2 \mathrm{H}_{2} \mathrm{SO}_{4}(m=x)(\mathrm{aq})+\mathrm{Pb}(\mathrm{c}) \rightleftharpoons 2 \mathrm{PbSO}_{4}(\mathrm{c})+2 \mathrm{H}_{2} \mathrm{O}(\mathrm{l}) \ldots$ & $a+0.9703$ & $b+0.00019$ \\
\hline
\end{tabular}

a International volts.

- This is a rounded figure. The author (Gerke) gave 0.000017 .

\section{TEMPERATURE COEFFICIENT OF ELECTROMOTIVE FORCE}

In order to calculate the heat of the storage battery reaction from electrochemical data, it is necessary to know also the temperature coefficient of emf. Of the earlier experimenters mentioned in table 3, only Dolezalek [2] and Thibaut [15] measured the temperature coefficients. Their values are given in columns 3 and 4 of table 5 . The NBS results are also reported in table 5. The values in column 6 are mean results of the two series of measurements on pasted plates having pure lead grids.

TABLE 5.-Change in electromotive force of the lead storage baitery with change in temperature

\begin{tabular}{|c|c|c|c|c|c|c|c|c|c|}
\hline \multirow{2}{*}{$\begin{array}{c}\text { Specific } \\
\text { gravity, } \\
25^{\circ} \mathrm{C} \\
25^{\circ} \mathrm{C}\end{array}$} & \multirow[b]{2}{*}{$\mathrm{H}_{2} \mathrm{SO}_{4}$} & \multicolumn{4}{|c|}{$\begin{array}{c}\text { Determinations on storage batteries, } \\
\qquad E E / \Delta T\end{array}$} & \multicolumn{4}{|c|}{$\begin{array}{l}\text { Calculated from electrode measurements, } \\
\qquad \Delta E / \Delta T\end{array}$} \\
\hline & & $\mid \begin{array}{c}\text { Dolezalek } \\
1898,0^{\circ} \\
\text { to } 24^{\circ} \mathrm{C}\end{array}$ & $\begin{array}{l}\text { Thibaut } \\
1913,15^{\circ} \\
\text { to } 50^{\circ} \mathrm{C}\end{array}$ & $\begin{array}{l}\text { Mean of } \\
\text { early } \\
\text { values }\end{array}$ & $\begin{array}{c}\text { NBS } \\
1933,0^{\circ} \\
\text { to } 40^{\circ} \mathrm{C}\end{array}$ & \begin{tabular}{|c|} 
Vosburgh \\
and \\
Craig \\
1929
\end{tabular} & $\begin{array}{l}\text { NBS } \\
1933\end{array}$ & $\begin{array}{c}\text { Harned } \\
\text { and } \\
\text { Hamer } \\
1935\end{array}$ & Mean \\
\hline 1 & 2 & 3 & 4 & 5 & 6 & 7 & 8 & 9 & 10 \\
\hline $\begin{array}{l}1.020 \\
1.030 \\
1.040 \\
1.050 \\
1.100\end{array}$ & $\begin{array}{r}\% \\
\% .05 \\
4.55 \\
6.04 \\
7.44 \\
14.72\end{array}$ & $\begin{array}{c}m v /{ }^{\circ} \mathrm{C} \\
-0.04 \\
+.06 \\
+.34\end{array}$ & $\begin{array}{r}m r /{ }^{\circ} \mathrm{C} \\
-0.06 \\
+.02 \\
+.08 \\
+.13 \\
+.26\end{array}$ & $\begin{array}{c}m v /{ }^{\circ} \mathrm{C} \\
-0.06 \\
+.02 \\
+.02 \\
+.10 \\
+.30\end{array}$ & $\begin{array}{r}m v /{ }^{\circ} \mathrm{C} \\
+0.10 \\
+.15 \\
+.29\end{array}$ & $\begin{array}{c}m v /{ }^{\circ} C \\
-0.05 \\
+.02 \\
+.07 \\
+.11 \\
+.22\end{array}$ & $\begin{array}{c}m v /{ }^{\circ} \mathrm{C} \\
+0.04 \\
+.09 \\
+.12 \\
+.24\end{array}$ & $\begin{array}{r}m v /{ }^{\circ} \mathrm{C} \\
-0.05 \\
+.01 \\
+.05 \\
+.08 \\
+.20\end{array}$ & $\begin{array}{c}m v{ }^{\circ} \mathrm{C} \\
-0.05 \\
+.02 \\
+.07 \\
+.10 \\
+.22\end{array}$ \\
\hline $\begin{array}{l}1.150 \\
1.200 \\
1.250 \\
1.280 \\
1.300\end{array}$ & $\begin{array}{l}21.38 \\
27.68 \\
33.80 \\
37.40 \\
39.70\end{array}$ & $\begin{array}{l}+.36 \\
+.31 \\
+.24 \\
+.19 \\
+.16\end{array}$ & $\begin{array}{l}+.29 \\
+.28 \\
+.25 \\
+.22 \\
+.20\end{array}$ & $\begin{array}{r}+.32 \\
+.30 \\
+.24 \\
+.20 \\
+.18\end{array}$ & $\begin{array}{r}+.33 \\
+.30 \\
+.22 \\
+.19 \\
+.18\end{array}$ & $\begin{array}{l}+.25 \\
+.23\end{array}$ & $\begin{array}{l}+.27 \\
+.26 \\
+.23 \\
+.20 \\
+.18\end{array}$ & $\begin{array}{l}+.23 \\
+.22 \\
+.21 \\
+.20 \\
+.19\end{array}$ & $\begin{array}{l}+.25 \\
+.24 \\
+.22 \\
+.20 \\
+.185\end{array}$ \\
\hline
\end{tabular}

By following a procedure similar to that described above for computing the emf from electrode combinations, the temperature coefficient may be calculated as indicated in the last column of table 4. 
The values thus determined are given in column 8 of table 5 . Columns 7 and 9 of this table give the values found by Vosburgh and Craig [16] and Harned and Hamer [19].

It is believed that tables 3 and 5 contain the best data available on emf and temperature coefficient, respectively, of the lead storage battery. The tables show the consistency of measurements made at different times and in different places. At most, the differences in corresponding values are a few millivolts. These data are of practical importance in the operation of batteries, and are used in this paper as a basis for calculating the heat of reaction. These calculations will be compared with the values calculated from thermochemical data.

\section{HEAT OF THE LEAD STORAGE-BATTERY REACTION}

\section{BASED ON ELECTROCHEMICAL DATA}

The thermodynamic relation between the electrical measurements and the heat of reaction is expressed by the Gibbs-Helmholtz equation, which, for the present purpose, may be written as follows:

$$
\Delta H=-\frac{2 \times 96,500}{4.1833}\left(E-T \frac{d E}{d T}\right)
$$

where $\Delta H$ is the heat of reaction in calories, 96,500 the value of the Faraday constant in international coulombs per equivalent, 2 the number of equivalents involved in the reaction, and 4.1833 the conversion factor to reduce the electrical measurements in international voltcoulombs to calories. Following the custom in thermochemical investigations in this country, the calorie used here is an artificial calorie defined as equal to 4.1833 international joules. As $T$, the absolute temperature, is $298.16^{\circ} \mathrm{K}$, the equation becomes

$$
\Delta H=-46,136\left(E-298.16 \frac{d E}{d T}\right)
$$

Using the values of $E$ and $d E / d T$ given in tables 3 and 5 , the heat of reaction, $\Delta H$, has been computed for the respective concentrations of sulfuric acid. The results of these calculations, based on electrochemical data, are given in columns 4,5 , and 6 of table 6 . Column 4 of this table contains values of the heat of reaction based on the mean of determinations made on cells prior to 1933 . These batteries were, it is believed, similar in materials and construction to batteries used commercially. In column 5 , values for $\Delta H$ are given based on cell measurements made at this Bureau in 1933. They differed from the other cells of previous experiments in the fact that they contained no antimony. Column 6 contains values of $\Delta H$ computed from the mean of the electrode measurements. These electrodes are better adapted to precise measurements, because the purity of materials can be better assured, the temperature can more easily be controlled, and the electrodes are free from local action, which is more or less inevitable in a commercial type of storage cell. 
TABLE 6.-Heat of the lead storage-battery reaction

[Comparison of the values calculated from thermal data with those calculated from electrical data.]

\begin{tabular}{|c|c|c|c|c|c|c|c|c|}
\hline \multirow{2}{*}{$\begin{array}{c}\text { Specific } \\
\text { gravity, } \\
\frac{25^{\circ} \mathrm{C}}{25^{\circ} \mathrm{C}}\end{array}$} & \multirow{2}{*}{$\mathrm{H}_{2} \mathrm{SO}_{4}$} & \multirow{2}{*}{$\begin{array}{l}\text { Heat of - } \\
\text { reaction } \\
\text { (thermo- } \\
\text { chemical) }\end{array}$} & \multicolumn{3}{|c|}{ Heat of reaction (electrochemical) } & \multicolumn{3}{|c|}{$\begin{array}{l}\text { Differences in heat of reaction. } \\
\text { Electrochemical - thermochem- } \\
\text { ical }\end{array}$} \\
\hline & & & $\begin{array}{c}\text { Batteries; } \\
\text { average } \\
\text { value } 1898 \\
\text { to } 1922\end{array}$ & $\begin{array}{c}\text { Batteries; } \\
\text { NBS } \\
\text { values } \\
1933\end{array}$ & $\begin{array}{c}\text { Electrodes; } \\
\text { average } \\
\text { value } 1929 \\
\text { to } 1935\end{array}$ & $\begin{array}{c}\text { Batteries, } \\
1898 \text { to } \\
1922\end{array}$ & $\begin{array}{l}\text { Batteries, } \\
\text { NBS } 1933\end{array}$ & $\begin{array}{c}\text { Electrodes, } \\
1929 \text { to } \\
1935\end{array}$ \\
\hline \multirow[t]{2}{*}{1} & 2 & 3 & 4 & 5 & 6 & 7 & 8 & 9 \\
\hline & ${ }_{2}^{\%}$ & ${ }_{-86}^{k c a l}$ & $k c a l$ & kcal & ${ }_{-86}^{k c a l}$ & $\%$ & $\%$ & \multirow{3}{*}{$\begin{array}{l}\% \\
+0.06 \\
+.05 \\
+.06 \\
+.05\end{array}$} \\
\hline 1 & 3.05 & -86.32 & -85.68 & & -86.28 & -0.75 & $\cdots$ & \\
\hline & $\begin{array}{l}4.55 \\
6.04\end{array}$ & $\begin{array}{l}-86.37 \\
-86.43\end{array}$ & $\begin{array}{l}-85.59 \\
-86.56\end{array}$ & -85.92 & $\begin{array}{l}-86.42 \\
-86.47\end{array}$ & $\begin{array}{l}-.91 \\
-.15\end{array}$ & +.59 & \\
\hline $\begin{array}{l}1.050 \\
1.100 \\
1.150 \\
1.200\end{array}$ & $\begin{array}{r}7.44 \\
14.72 \\
21.38 \\
27.68\end{array}$ & $\begin{array}{l}-86.53 \\
-87.44 \\
-88.87 \\
-90.99\end{array}$ & $\begin{array}{l}-86.20 \\
-85.98 \\
-87.37 \\
-90.32\end{array}$ & $\begin{array}{l}-85.83 \\
-86.54 \\
-87.97 \\
-90.46\end{array}$ & $\begin{array}{l}-86.66 \\
-87.45 \\
-89.12 \\
-91.28\end{array}$ & $\begin{array}{r}+.38 \\
+1.70 \\
+1.72 \\
+0.74\end{array}$ & $\begin{array}{r}+.82 \\
+1.04 \\
+1.03 \\
+0.59\end{array}$ & $\begin{array}{l}-.15 \\
=.01 \\
=.28 \\
-.32\end{array}$ \\
\hline $\begin{array}{l}1.250 \\
1.280 \\
1.300\end{array}$ & $\begin{array}{l}33.80 \\
37.40 \\
39.70\end{array}$ & $\begin{array}{l}-93.65 \\
-95.37 \\
-96.51\end{array}$ & $\begin{array}{l}-93.08 \\
-94.93 \\
-96.22\end{array}$ & $\begin{array}{l}-93.77 \\
-95.57 \\
-96.63\end{array}$ & $\begin{array}{l}-93.66 \\
-95.25 \\
-96.36\end{array}$ & $\begin{array}{l}+.61 \\
+.46 \\
+.30\end{array}$ & $\begin{array}{l}-.13 \\
-.21 \\
-.12\end{array}$ & $\begin{array}{l}-.01 \\
+.13 \\
+.16\end{array}$ \\
\hline \multicolumn{2}{|c|}{ Average. } & & & & & \pm 0.77 & \pm 0.57 & \pm 0.12 \\
\hline
\end{tabular}

a $T$ his concentration corresponds to $n_{1}=200$ moles of $\mathrm{H}_{2} \mathrm{O}$.

The results for the electrode measurements are the mean of all the results reported in tables 3 and 5, beginning with those of Vosburgh and Craig in 1929 and including the later observations made at this Bureau in 1933 and the still later measurements of Harned and Hamer in 1935 .

The NBS results of 1933 on batteries and electrodes have not been published previously, because at that time it was felt that more accurate determinations were needed to establish the chemical reactions occurring in the lead storage battery. The work of Vinal and Craig [1] published in 1935 strongly supports the double-sulfate theory, and affords the required foundation for comparing the heat of reaction of the battery calculated from electrochemical data with the heat of reaction calculated from purely thermal data.

\section{BASED ON THERMOCHEMICAL DATA}

In calculating the heat of reaction thermochemically, a dilute solution of sulfuric acid, having the proportions of 1 mole of acid to 200 moles of water was chosen as the starting point. The heat of formation, $\Delta H f$, at $18^{\circ} \mathrm{C}$, of the various constituents is written beneath their respective symbols.

$$
\begin{aligned}
& \mathrm{PbO}_{2}(\mathrm{c})+2\left[\mathrm{H}_{2} \mathrm{SO}_{4}+200 \mathrm{H}_{2} \mathrm{O}\right](\mathrm{l})+\mathrm{Pb}(\mathrm{c}) \rightleftharpoons 2 \mathrm{PbSO}_{4}(\mathrm{c})+402 \mathrm{H}_{2} \mathrm{O}(\mathrm{l}) \\
& \begin{array}{lllll}
-65,000 & 2(-211,500) & 0 & 2(-218,500) & 2(-68,370)
\end{array}
\end{aligned}
$$

These values are taken from the book by Bichowsky and Rossini [4]. From these numerical values, the heat of reaction, $\Delta H$, is $-85,740$ cal. A correction is necessary to convert this to the equivalent heat of reaction at $25^{\circ} \mathrm{C}$, which is a more convenient temperature. Using a correction factor of $45.4 \mathrm{cal} /{ }^{\circ} \mathrm{C}$ for the reaction, as expressed by the 
above equation, the heat of the reaction at $25^{\circ} \mathrm{C}$ becomes $-85,420$ cal. The minus sign indicates that the heat content of constituents on the right of the above equation is less than that of those on the left, and that heat is evolved in the reaction.

Considered from a purely chemical point of view, the changes in the heat content of sulfuric-acid solutions from one concentration to another vary by the amount of heat liberated as the solution is diluted. Eventually a point is reached when no more heat is liberated and the solution is infinitely dilute and its volume is infinitely great. The amount of heat energy liberated by the dilution process may be calculated from the relative apparent molal heat contents given in column 5 of table 1 .

In order to calculate the heat of reaction for an infinitely dilute sulfuric-acid solution, this value must be added to this relative apparent molal heat content of a solution of $\mathrm{H}_{2} \mathrm{SO}_{4} \cdot 200 \mathrm{H}_{2} \mathrm{O}$. As shown by column 5 of table 1 , this is $5.41 \mathrm{kcal}(5410 \mathrm{cal})$ per mole. Two moles are involved, whence $-85,420+10,820=-74,600$ as the heat of reaction at infinite dilution. In a cell, however, the energy of the reaction depends on the differential changes in the heat contents, that is, upon the relative partial molal heats of the acid and the water. Values for these are given in columns 7 and 8 of table 1 . At infinite dilution these values are zero and the heat of reaction in a cell is precisely the same as the thermochemical or calorimetric heat of reaction. At any finite concentration there is a difference, amounting to about $3 \mathrm{kcal} / \mathrm{mole}$ of $\mathrm{H}_{2} \mathrm{SO}_{4}$ for a solution containing 40 percent of $\mathrm{H}_{2} \mathrm{SO}_{4}$. With due regard for the algebraic signs, the heat of reaction as it occurs in a storage battery at any finite concentration equals the heat of reaction at infinite dilution plus twice the sum of the relative partial molal heat contents of $\mathrm{H}_{2} \mathrm{SO}_{4}$ and $\mathrm{H}_{2} \mathrm{O}$. The factor 2 comes from the use of 2 moles each of $\mathrm{H}_{2} \mathrm{SO}_{4}$ and $\mathrm{H}_{2} \mathrm{O}$ for each mole of lead dioxide. These matters were more fully explained in an earlier part of this paper.

\section{COMPARISON OF THERMOCHEMICAL AND ELECTROCHEMICAL DATA}

Table 6 gives in parallel columns the heat of reaction calculated from thermochemical data and from electrochemical data throughout a range of acid concentrations from 2.65 to 39.70 percent. This covers the range used in lead-acid batteries.

The agreement is rather remarkable, considering the numerous sources of error. These include errors in determining the heat of formation of the various constituents and their heat capacities, and the errors of graphical methods of determining tangents for computing the partial quantities. On the electrochemical side, there are possible uncertainties and sources of error in measuring the emf and temperature coefficients as well as errors in temperature control.

The uncertainties about standards of emf and temperature control are probably greater in the earlier measurements on batteries, and this is perhaps the reason that these are not consistently in as good agreement with the later NBS measurements of 1933 or with the thermochemical calculations. One fact, however, seems clearly established, namely, that the fundamental chemical reaction, as expressed by the equation of the double-sulfate theory, must be correct. To have used 
any other than 2 moles each of $\mathrm{H}_{2} \mathrm{SO}_{4}$ and $\mathrm{H}_{2} \mathrm{O}$ for 2 faradays in the calculations would have resulted in large discrepancies. Good agreement between the heats of reaction based on thermochemical and electrochemical data may be regarded as a thermodynamic proof of the correctness of the double-sulfate theory.

The uncertainties in the heat of formation of the solids are probably greater than in the case of the solutions, but they are probably not more than one or at most a few percent of the heat of reaction of the cell. In comparing values for differing concentrations of acid, any error in the heat of formation of the solids becomes a constant factor, and the corresponding differences in electromotive force from one concentration to another should depend on the solutions alone. Shankman and Gordon [20] have recently determined the vapor pressure of aqueous solutions of sulfuric acid. Using their activities of water and their activity coefficients of $\mathrm{H}_{2} \mathrm{SO}_{4}$ for molal concentrations of one and six and interpolated values from column 10, table 3 of this paper, for corresponding concentrations, the differences in emf were found to be:

$$
\begin{aligned}
& \text { Shankman and Gordon (calculated } \\
& \text { from vapor pressure)__._. } \\
& \text { NBS electrodes of } 1933 \text { (observed)__. } 0.201 \text { volt. }
\end{aligned}
$$

The agreement between our observed values and those calculated from their vapor-pressure measurements is very good over a wide range of acid concentrations.

Of the electrochemical measurements, the greatest uncertainty is in the measurement of the temperature coefficient, but this is not the predominating term of the electrochemical calculations. Probably the most accurately determined values of emf and its temperature coefficient are those derived from the electrode measurements, and it is significant that these are in the best agreement among themselves and with the thermochemical data. Column 9 in table 6 shows throughout an acid range from 3 to 40 percent of $\mathrm{H}_{2} \mathrm{SO}_{4}$ that the average difference of 11 comparisons of the heat of reaction is only \pm 0.12 percent, with a maximum difference of 0.3 percent. Whatever uncertainty may attach to the heat of formation of the solids, the values which have been used must be very close to the true values; otherwise such close agreement of calculations based on entirely unrelated data would not be expected.

\section{EFFECT OF PRESSURE ON ELECTROMOTIVE FORCE}

Partial molal volumes of sulfuric acid and water may be calculated by following in a general way the procedure for obtaining analogous quantities of heat content and heat capacity. A few of the partial molal volumes have been calculated in order to estimate the change in emf with change in pressure. Inquiries about the magnitude of this effect are often made. Several attempts to measure the change experimentally have been reported. Gilbault [21], using 8.8 percent acid, found $-0.0012 \mathrm{v}$ per $100 \mathrm{~atm}$, and Dolezalek [2], using 20 percent acid, found $-0.0011 \mathrm{v}$ per $100 \mathrm{~atm}$ increase in pressure. The minus sign is used to indicate a decrease in emf with increase in pressure. The agreement between these results is perhaps accidental. 
The change in volume of the cell as a whole depends on the change in volume of each constituent. Actually, when a cell containing a solution of less than 37 percent of $\mathrm{H}_{2} \mathrm{SO}_{4}$ discharges, there is a small increase in volume. This should not be confused with the decrease in volume of the solution which occurs during the same process. Considering the equation for the reaction according to the double-sulfate theory, it is possible to write the molal volumes of the solid constituents and the partial molal volumes of the acid and water, and take the difference of the sums on the two sides of the equation. For example, a cell containing a 10-percent solution would give

\begin{tabular}{|c|c|c|c|}
\hline \multicolumn{2}{|l|}{ Left side } & \multicolumn{2}{|l|}{ Right side } \\
\hline $\begin{array}{l}\mathrm{PbO}_{2}(\mathrm{c}) \\
\mathrm{Pb}(\mathrm{c}) \\
2 \mathrm{H}_{2} \mathrm{SO}_{4}\left(2 \bar{V}_{2}\right)(\mathrm{aq})\end{array}$ & $\begin{array}{l}m l \\
25.52 \\
18.27 \\
78.98\end{array}$ & $\begin{array}{l}2 \mathrm{PbSO}_{4}(\mathrm{c}) \\
2 \mathrm{H}_{2} \mathrm{O}\left(2 \bar{V}_{1}\right)(\mathrm{aq})\end{array}$ & $\begin{array}{c}m l \\
97.83 \\
36.02 \\
\end{array}$ \\
\hline Total_.... & 122. 77 & Total_...- & 133. 85 \\
\hline & & & $=11.08$ \\
\hline
\end{tabular}

The difference is an increase of $11.08 \mathrm{ml}$ in volume for the passage of 2 faradays in a discharge direction. The work done against an external pressure of $1 \mathrm{~atm}$ is $11.08 \mathrm{ml}-\mathrm{atm}$. Since 1 liter-atm equals $101.33 \mathrm{v}$-coulombs, this difference produces a change of emf equal to $-0.006 \mathrm{mv} / \mathrm{atm}$. The change is very small and unimportant from an engineering point of view.

Calculated values for several concentrations within the range used in batteries are shown in table 7 . Below 37 percent the values are negative, that is, the emf decreases with increased pressure. At about 37 percent the value of $d E / d P$ is zero, and for higher concentrations the effect is positive.

TABLE 7.-Change in electromotive force of a lead-acid storage cell with change in pressure

[ $\Delta V$ is the total change in volume of the cell, including the solid constituents and the solution at 1 atm]

\begin{tabular}{|c|c|c|c|c|c|c|c|c|c|}
\hline \multicolumn{2}{|c|}{$\begin{array}{c}\text { Concentration of } \\
\mathrm{H}_{2} \mathrm{SO}_{4}\end{array}$} & \multirow{2}{*}{$\begin{array}{c}\text { Density, } \\
\frac{25^{\circ} \mathrm{C}}{4^{\circ} \mathrm{C}}\end{array}$} & \multirow{2}{*}{$\begin{array}{l}\text { Specific } \\
\text { volume }\end{array}$} & \multirow{2}{*}{$\begin{array}{c}\text { Molal } \\
\text { volume }\end{array}$} & \multicolumn{2}{|c|}{$\begin{array}{c}\text { Partial molal } \\
\text { volumes }\end{array}$} & \multirow{2}{*}{$\begin{array}{c}\Delta V \\
\text { per } 2 \\
\text { faradays }\end{array}$} & \multirow{2}{*}{$\begin{array}{l}\text { Equiva- } \\
\text { lent volt- } \\
\text { coulombs }\end{array}$} & \multirow{2}{*}{$d E / d P$} \\
\hline Percent & Molality & & & & $\begin{array}{l}\text { Water, } \\
\vec{V}_{1}\end{array}$ & $\begin{array}{c}\text { Acid, } \\
\bar{V}_{\sharp}\end{array}$ & & & \\
\hline 1 & 2 & 3 & 4 & 5 & 6 & 7 & 8 & 9 & 10 \\
\hline & $\begin{array}{l}0.5262 \\
1.1329\end{array}$ & $\begin{array}{l}\text { 1. } 02996 \\
\text { 1. } 06397\end{array}$ & $\begin{array}{c}m l \\
0.970911 \\
.939876\end{array}$ & $\begin{array}{c}m l \\
18.236 \\
18.438\end{array}$ & $\begin{array}{l}m l \\
18.03 \\
18.01\end{array}$ & $\begin{array}{l}m l \\
39.44 \\
39.49\end{array}$ & $\begin{array}{r}m l \\
+11.22 \\
11.08\end{array}$ & $\begin{array}{l}1.137 \\
1.123\end{array}$ & $\begin{array}{l}\text { mv/atm } \\
-0.0059 \\
-.0058\end{array}$ \\
\hline $\begin{array}{l}15 . \\
20\end{array}$ & $\begin{array}{l}1.7993 \\
2.5490 \\
3.3987\end{array}$ & $\begin{array}{l}\text { 1. } 09943 \\
\text { 1. } 13649 \\
1.17504\end{array}$ & $\begin{array}{l}.909562 \\
.879902 \\
.851035\end{array}$ & $\begin{array}{l}\text { 18. } 673 \\
18.945 \\
19.263\end{array}$ & 17.94 & 40.85 & 8.22 & 0.833 & -.0043 \\
\hline $\begin{array}{l}30 \ldots \\
35\end{array}$ & $\begin{array}{l}\text { 4. } 3698 \\
\text { 5. } 4903\end{array}$ & $\begin{array}{l}\text { 1. } 21501 \\
\text { 1. } 25628\end{array}$ & $\begin{array}{r}.823038 \\
.796001\end{array}$ & $\begin{array}{l}19.637 \\
20.077\end{array}$ & 17.76 & 43.45 & 2. 66 & .270 & -.0014 \\
\hline & 6. 7974 & 1. 29904 & .769799 & 20.592 & 17.57 & 45.29 & -1.40 & .142 & +.0007 \\
\hline $\begin{array}{l}45 \ldots \\
50\end{array}$ & $\begin{array}{r}8.3423 \\
10.1962\end{array}$ & $\begin{array}{l}\text { 1. } 34379 \\
1.39113\end{array}$ & $\begin{array}{l}.744164 \\
.718840\end{array}$ & $\begin{array}{l}21.191 \\
21.882\end{array}$ & 17.47 & 45.90 & -2.82 & .286 & +.0015 \\
\hline
\end{tabular}




\section{CONCLUSION}

The authors' justification for assuming the double-sulfate theory of reactions rests on their previously published paper on the fundamental chemical reaction in the lead storage battery. This reaction having been verified by experimental results, the next step was to calculate the heat of reaction by thermodynamics. Before doing so, it was necessary to obtain better thermochemical data for sulfuric-acid solutions. The thermochemical tables presented in this paper have been compiled on the basis of critically selected data with the help of Dr. Rossini, to whom the authors make grateful acknowledgments. Similarly, a critical selection of emf and temperature coefficient data have been made, including some of the authors' experimental results. These data should be of engineering value in battery operation. It is of some interest that the average emf of a cell containing electrolyte of specific gravity 1.280 at $25^{\circ} \mathrm{C}$, which is used in engineering work, is $2.125 \mathrm{v}$ per cell. This ist he average resulting from long experience and measurements on many batteries. On the other hand, the laboratory measurements made with potentiometers and other precision equipment indicate 2.125 as the weighted mean value from electrode measurements and the NBS battery determination of 1933 . Equally precise values are now available for other concentrations of electrolyte.

The Gibbs-Helmholtz equation was used to compute the heat of reaction from the electrochemical data. Comparing these results with the thermochemical calculations, it is seen that the agreement is remarkably good. To have assumed any other factor than 2 for the equivalents of $\mathrm{H}_{2} \mathrm{SO}_{4}$ and $\mathrm{H}_{2} \mathrm{O}$ for the passage of 1 faraday would have resulted in large discrepancies. This fact may be regarded, therefore, as a thermodynamic proof of the validity of the doublesulfate theory of the chemical reaction.

\section{REFERENCES}

[1] G. W. Vinal and D. N. Craig, J. Research NBS 14, 449 (1935) RP778.

[2] F. Dolezalek, Theory of the Lead Accumulator. John Wiley \& Sons, New York, N. Y. (1904).

[3] G. N. Lewis and M. Randall, Thermodynamics and the Free Energy of Chemical Substances. McGraw-Hill Book Co., Inc., New York, N. Y., (1923)

[4] F. R. Bichowsky and F. D. Rossini, The Thermochemistry of Chemical Substances. Reinhold Publishing Corporation, New York, N. Y., (1936).

[5] E. Lange, J. Monheim, and A. L. Robinson, J. Am. Chem. Soc. 55, 4733 (1933).

[6] F. D. Rossini, BS J. Research 6, 791 (1931) RP305.

[7] F. D. Rossini, BS J. Research \&, 313 (1930) RP151.

[8] E. Biron, Russkoe Fiziko-Khimicheskoe Obshehestvo, 31, 201 (1899).

[9] S. Socolik, Z. Phys. Chem. 158, 305 (1932).

[10] F. Bode, Z. Angw. Chem. R, 244 (1889).

[11] P. Pascal and Garnier, Bul. Soc. Chim. 27, 8 (1920).

[12] M. D. Taylor. Thesis; University of California (1931).

[13] G. W. Vinal, Storage Batteries, 2d ed. John Wiley \& Sons, Inc., New York• N. Y. (1930).

[14] A. Kendrick, Z. Elektrochem. 7, 53 (1900).

[15] R. Thibaut, Z. Elektrochem. 19, 881 (1913).

[16] W. C. Vosburgh and D. N. Craig, J. Am. Chem. Soc. 51, 2009 (1929).

[17] W. E. Henderson and G. Stegeman, J. Am. Chem. Soc. 40, 87 (1918).

[18] R. H. Gerke, J. Am. Chem. Soc. 44, 1695 (1922).

[19] H. S. Harned and W. J. Hamer, J. Am. Chem. Soc. 5\%, 33 (1935).

$[20]^{-}$S. Shankman and A. R. Gordon, J. Am. Chem. Soc. 61, 2370 (1939).

[21] H. Gilbault, Compt. rend. 113, 465 (1891).

WASHINGTON, January 23, 1940. 